\title{
Vibration Fatigue Analysis of Two-stroke Free Piston Engine using Frequency Response Approach
}

\author{
Md. Mustafizur Rahman and Ahmad Kamal Ariffin
}

\author{
Computational and Experimental Mechanics Group \\ Department of Mechanical and Materials Engineering \\ Universiti Kebangsaan Malaysia \\ 43600 UKM, Bangi, Selangor, \\ Malaysia

\begin{abstract}
This paper describes a vibration fatigue analysis techniques to predict the fatigue life using the frequency response approach. The life prediction results are useful for improving the component design at a very early development stage. The finite element modeling and frequency response analysis have been performed using the finite element analysis software. In addition, the fatigue life prediction was carried out using both the time domain and frequency response methods. From the results, it is observed that the Dirlik method gives the best comparable results pseudo-static time domain approach with the frequency response techniques. This paper also describes how this technique can be implemented in the finite element environment to rapidly identify critical areas in the structure. This approach is capable of determining premature products failure phenomena. Therefore, it can reduce time to market, improve product reliability and customer confidence.
\end{abstract}

Keywords: Fatigue, vibration, power spectral density function, time domain, frequency response.

\section{ABSTRAK}

Kertas kerja ini menerangkan teknik analisis lesu getaran bagi meramalkan hayat lesu menggunakan pendekatan sambutan frekuensi. Keputusan ramalan hayat adalah berguna bagi memperbaiki reka bentuk komponen sejak peringkat awal pembangunan. Kaedah unsur terhingga dan analisis sambutan frekuensi telah dilaksanakan menggunakan perisian analisis unsur terhingga. Sebagai tambahan, ramalan hayat lesu dijalankan menggunakan kedua-dua kaedah domain masa dan sambutan frekuensi. Dari keputusan, dapat diperhatikan kaedah Dirlik memberi perbandingan terbaik dengan pendekatan domain masa pseudostatik dengan teknik sambutan frekuensi. Kertas kerja ini juga menerangkan bagaimana teknik ini boleh dilaksanakan dalam sekitaran unsur terhingga bagi mengenalpasti dengan segera kawasan kritikal dalam struktur. Pendekatan ini berupaya menentukan fenomena kegagalan produk yang belum masanya. Oleh itu, ia boleh menjimat masa kepasaran, baiki keboleharapan produk dan keyakinan pengguna.

Kata kunci: Lesu, getaran, fungsi ketumpatan spektral kuasa, domain masa, sambutan frekuensi. 


\section{INTRODUCTION}

Structures and mechanical components are frequently subjected to oscillating loads of random in nature. Random vibration theory has been introduced for more then three decades to deal with all kinds of vibration behaviour when random is concerned. Since fatigue is one of the major causes when component failure is considered, fatigue life prediction has become a major subject in almost any random vibration (Bolotin 1984; Newland 1993; Soong \& Grigoriu 1993). Nearly all structures or components have traditionally been designed using time based structural and fatigue analysis methods. However, by developing a frequency based fatigue analysis approach, the true composition of the random stress or strain responses can be retained within a much optimized fatigue design process.

Structural analysis can be carried out in either the time domain or frequency response approaches. In the time domain the input takes the form of a time history of load. The structural response can be derived using the finite element representation coupled with a transient solution approach. The output of this model is also expresses as a time history. Time domain fatigue approach consists of a number of steps. The first is to count the number of stress cycles in the response time history (Suresh 2002 \& Stephen et al.2001).This is done through a process called rain flow cycle counting. Damage from each cycle is determined, typically from an $\mathrm{S}-\mathrm{N}$ curve. The damage is then summed over all cycles using linear damage summation techniques to determine the total life. The purpose of presenting these basic fatigue concepts is to emphasize that fatigue analysis is generally thought of as a time domain approach, i.e. all of the operations are based on time descriptions of the load function. This paper shows that an alternative frequency domain (Newland 1993; Wirsching et al. 1995; Bishop \& Sherratt 2000) fatigue approach can be more appropriate.

A vibration analysis is usually carried out to ensure that potentially catastrophic structural natural frequencies or resonant modes are not excited by the frequencies present in the applied load. It is often easier to obtain a power spectral density (PSD) of stress rather than a time history. The dynamic analysis of complicated finite element models is considered in this study. It is beneficial to carry out a rapid frequency response analysis instead of a computationally intensive transient dynamic analysis in the time domain. A finite element analysis based in the frequency domain can simplify the problem considerably. The designer can carry out a frequency response analysis on the finite element (FE) model to determine the transfer function between load and stress in the structure. Using this, simply multiplied the PSD of load by the transfer function to arrive at the PSD of stress.

The time domain $S-N$ analysis and approach in the frequency domain are discussed briefly in this paper. A comparison study between the different fatigue analysis techniques is presented for computing fatigue damage on vibrating components.

\section{THEORETICAL BASIS OF VIBRATION FATIGUE}

Spectral fatigue analysis techniques are used a power spectral density of stress or strain is usually the input from which a fatigue life estimate is required. The PSD (Newland 1993; Soong \& Grigoriu 1993) is simply an alternative way of representing an equivalent time history of stress or strain. In fact there is a mathematical link or transformation which can be used move from time domain to frequency domain as shown in Figure 1(a). The information which is extracted from the frequency domain directly (which is used to compute fatigue damage), are the moments of the PSD. These moments are used to compute all of the information required to estimate fatigue damage, in particular the probability density function (PDF) of stress ranges and the expected numbers of zero crossings and peaks per second. The $n$th moments of the PSD is computed by Equation (1).

$$
M_{n}=\int_{0}^{\infty} f^{n} G(f) d f
$$

where $f$ is the frequency and $G(f)$ is the single sided PSD at frequency of $f \mathrm{~Hz}$.

A method for computing these moments is shown in Figure 1(b). Some very important statistical parameters can be computed from these moments. These parameters are root mean square (RMS), number of zero crossing with positive slope $(E[0])$, number of peaks per second $(E[P])$.The formulas in Equation (2) highlight these properties of the spectral moments. 


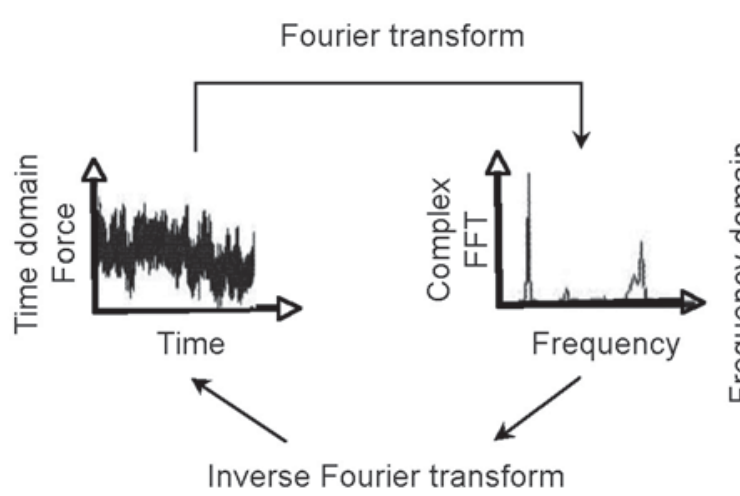

(a)

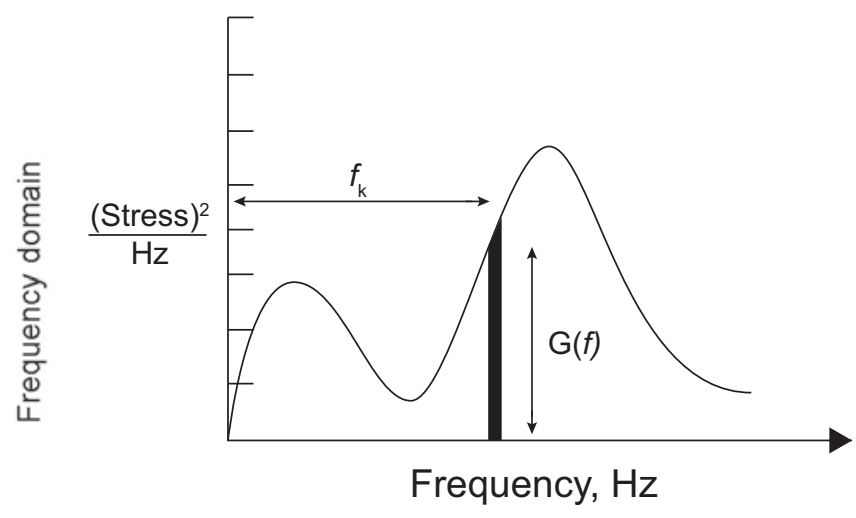

(b)

FIGURE 1. (a) Transformation between the time and frequency domains; (b) Moments of spectral from a PSD

$$
\begin{aligned}
& R M S=\sqrt{m_{0}} ; \quad E[0]=\sqrt{\frac{m_{2}}{m_{0}}} \\
& E[P]=\sqrt{\frac{m_{4}}{m_{2}}}
\end{aligned}
$$

where $m_{0^{\prime}} m_{1}, m_{2^{\prime}}$ and $m_{4}$ are the zero, $1^{\text {st }}, 2^{\text {nd }}$ and $4^{\text {th }}$ order moment of area of the PSD respectively.

Another important property of spectral moments is the fact that it is possible to express the irregularity factor as a function of the zero, second and fourth order spectral moments, as shown in Equation (3).

$$
\gamma=\frac{E[0]}{E[P]}=\frac{m_{2}}{\sqrt{m_{0} m_{4}}}
$$

The irregularity factor $\gamma$ is an important parameter that can be used to evaluate how concentrated near a central frequency the process is. So it can be used to determinate whether or not the process is narrow band or wide band. Irregularity factor varies between 1 and 0 . A narrow band process (irregularity factor approaches to 1) is characterized by only one predominant central frequency meaning that the number of peaks per second is very similar to the number of zero crossings of the signal. The value of irregularity factor tends to 0 when the signal contains a significant amount of energy at all frequencies.

\section{FATIGUE ANALYSIS METHODS IN THE FREQUENCY DOMAIN}

This section describes a variety of approaches for computing fatigue life or damage directly from the PSD of stress as opposed to a time history.
The techniques fall into two categories, those that compute fatigue life directly and those that compute range mean histograms as an intermediate stage. Bendat (1964) proposed first significant step towards a method of determining fatigue life from PSDs. Bendat showed that the probability density function of peaks for a narrow band signal tended towards Rayleigh distributions as the bandwidth reduced. Furthermore, for a narrow banded time history Bendat assumed that all positive peaks in the time history would be followed by corresponding troughs of similar magnitude regardless of whether they actually formed stress cycles. Using this assumption the pdf of stress range would also tend to a Rayleigh distribution. To complete his solution method, Bendat used a series of equations derived by Rice (1954) to estimate the expected number of peaks using moments of area beneath the PSD. Bendat's narrow band solution for the range mean histogram is therefore expressed in the Equation (4).

$$
E[D]=\sum_{i} \frac{n_{i}}{N\left(S_{i}\right)}=\frac{S_{t}}{k} \int S^{b} p(S) d S
$$

where $N\left(S_{i}\right)$ is the number of cycles of stress range $S$ occurring in $T$ seconds, $n_{i}$ is the actual counted number of cycle, $S$ is the total number of cycles equals to $E[P]$. $T$. In order to compute fatigue damage over the lifetime of the structure in seconds the form of materials $S-N$ data must be defined using the parameters $k$ and $b$.The typical $S-N$ curve is shown in Figure 2. This figure simply shows that, under constant amplitude cyclic loading, a linear relationship exists between cycles to failure $(N)$ and applied stress range $(S)$ when plotted on log-log paper. There are two 


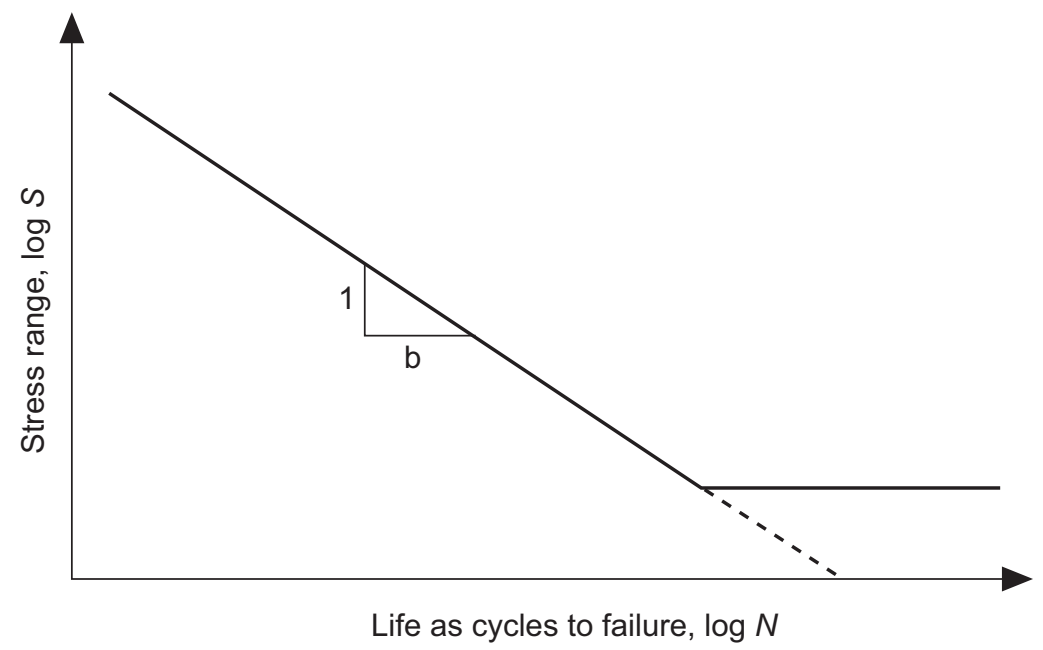

FIGURE 2. Typical S-N curve

alternative ways of defining this relationship, as given in Equation (5).

$$
N=k S^{-b}, b=-\frac{1}{b 1}, \text { and } k=(S R / 1)^{b}
$$

Many expressions have been proposed to correct the conservatism associated with this solution. Most were developed with reference to offshore platform design where interest in the techniques has existed for many years. In general, they were produced by generating sample time histories from PSDs using Inverse Fourier Transform techniques, from which a conventional rainflow cycle count was then obtained. The solutions of Wirsching (Wirsching et al. 1980), Tunna (1984), Choudhury \& Dover (1985) , Steinberg (Bishop \& Zhihua 1991), and Hancock (Kam \& Dover 1988) were all derived using this approach. They are all expressed in terms of the spectral moments up to $m_{4}$.

(i) Tunna Solution,

$$
p(S)_{T}=\left[\frac{S}{4 \gamma m_{0}} e^{-\frac{S^{2}}{8 \gamma m_{0}}}\right]
$$

(ii) Wirsching Solution,

$$
E[D]_{\text {Wirsching }}=E[D]_{N B}\left\lfloor a+(1-a)(1-\varepsilon)^{c}\right\rfloor
$$

where

$a=0.926-0.033 b ; c=1.587 b-2.323 ; \varepsilon=\sqrt{1-\gamma^{2}}$
This solution is given in the form of an equivalent stress range parameter $S_{e q^{\prime}}$ where

$$
S_{e q}=\left[\int_{0}^{\infty} S^{b} p(S) d S\right]^{\frac{1}{b}}
$$

(iii) Hancock's equivalent stress,

$$
\left(S_{e q}\right)_{\text {Hancock }}=\left(2 \sqrt{2 m_{0}}\right)\left[\gamma \Gamma\left(\frac{b}{2}+1\right)\right]^{\frac{1}{b}}
$$

(iv) Chaudhury and Dover equivalent stress,

$$
\begin{aligned}
\left(S_{e q}\right)_{C \& D}= & \left(2 \sqrt{2 m_{0}}\right)\left[\frac{\varepsilon^{b+2}}{2 \sqrt{\pi}} \Gamma\left(\frac{b+1}{2}\right)\right. \\
& +\frac{\gamma}{2} \Gamma\left(\frac{b+2}{2}\right) \\
& \left.+\operatorname{erf}^{*}(\gamma) \frac{\gamma}{2} \Gamma\left(\frac{b+2}{2}\right)\right]^{\frac{1}{b}}
\end{aligned}
$$

where,

$$
\begin{aligned}
\operatorname{erf}^{*}(\gamma)= & 0.3012 \gamma+0.4916 \gamma^{2}+0.9181 \gamma^{3} \\
& -2.354 \gamma^{4}-3.3307 \gamma^{5} \\
& +15.6524 \gamma^{6}-10.7846 \gamma^{7}
\end{aligned}
$$

(v) Steinberg Solution,

$$
\begin{aligned}
\left(S_{\text {eq }}\right)_{\text {Steinberg }}= & {\left[0.683\left(2 \sqrt{m_{0}}\right)^{b}\right.} \\
& +0.271\left(4 \sqrt{m_{0}}\right)^{b} \\
& \left.-0.043\left(6 \sqrt{m_{0}}\right)^{b}\right]^{\frac{1}{b}}
\end{aligned}
$$


The fatigue damage can then easily be obtained by substituting this into the general damage equation used when deriving the narrow band solution

$$
E[D]=\frac{E[P] T}{k} S_{e q}
$$

(vi) The Dirlik formula (Dirlik 1985; Bishop \& Sherratt 2000) is given below

$$
N(S)=E[P] T p(S)
$$

where $N(S)$ is the number of stress cycles of range $S\left(\mathrm{~N} / \mathrm{mm}^{2}\right)$ expected in $T$ seconds, $E[P]$ is the expected number of peaks and $p(S)$ is the probability density function.

$$
p(S)=\frac{\frac{D_{1}}{Q} e^{\frac{-z}{Q}}+\frac{D_{2} Z}{R^{2}} e^{\frac{-z^{2}}{2 R^{2}}}+D_{3} Z e^{\frac{-z^{2}}{2}}}{2 \sqrt{m_{0}}}
$$

where,

$$
\begin{aligned}
& x_{m}=\frac{m_{1}}{m_{0}} \sqrt{\frac{m_{2}}{m_{4}}} ; \gamma=\frac{m_{2}}{\sqrt{m_{0} m_{4}}} ; \\
& D_{1}=\frac{2\left(x_{m}-\gamma^{2}\right)}{1+\gamma^{2}} ; R=\frac{\gamma-x_{m}-D_{1}^{2}}{1-\gamma-D_{1}+D_{1}^{2}} ; \\
& Z=\frac{S}{2 \sqrt{m_{0}}} ; D_{2}=\frac{1-\gamma-D_{1}+D_{1}^{2}}{1-R} ; \\
& D_{3}=1-D_{1}-D_{2} ; Q=\frac{1.25\left(\gamma-D_{3}-D_{2} R\right)}{D_{1}}
\end{aligned}
$$

where $x_{m^{\prime}} D_{1^{\prime}} D_{2^{\prime}} D_{3^{\prime}} Q$ and $R$ are all functions of $m_{\sigma^{\prime}} m_{1^{\prime}} m_{2}$ and $m_{4^{\prime}} Z$ is a normalized variable. All of above discussed methods are determining fatigue life from PSDs stress.
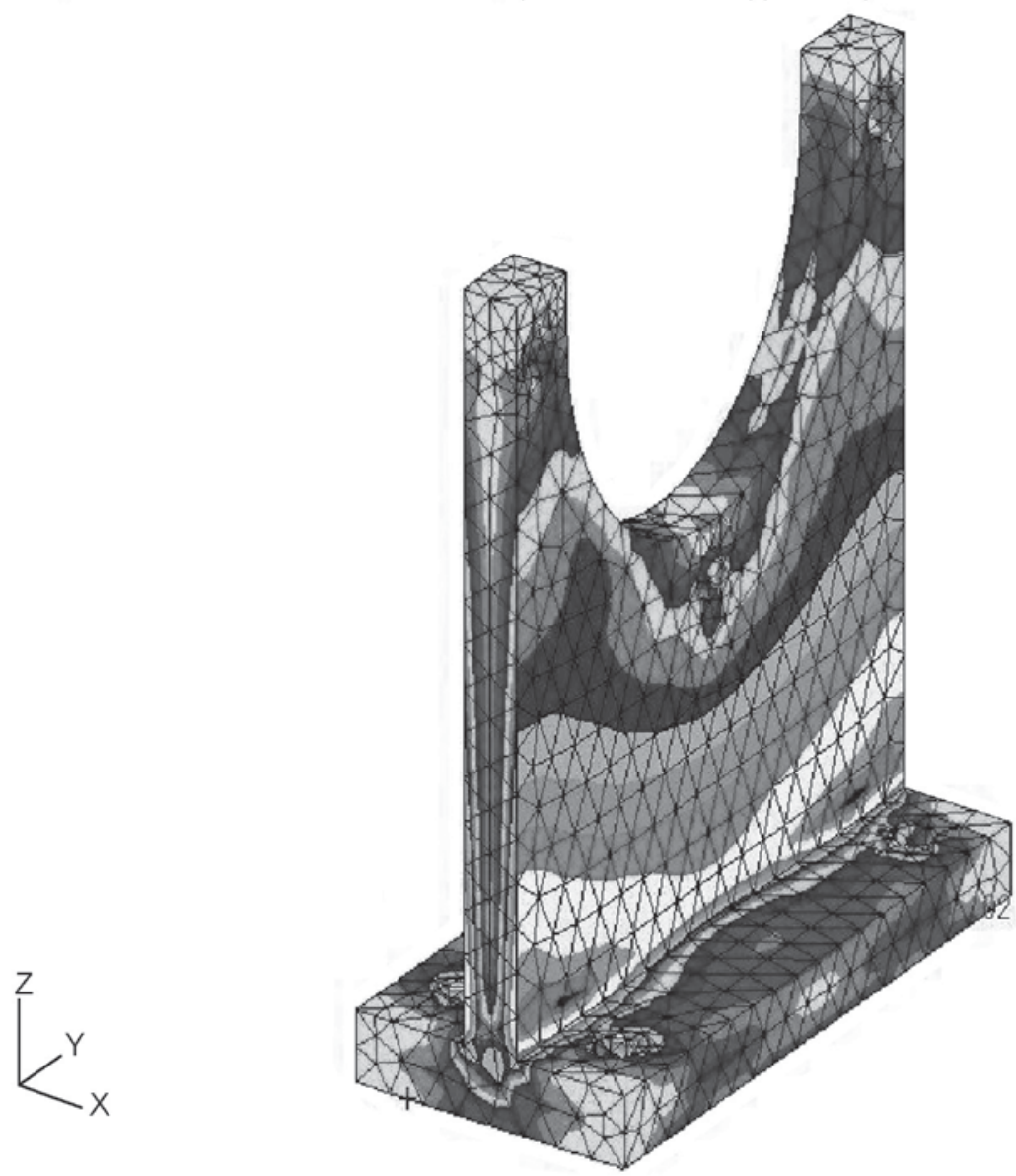

FIGURE 3. Von Mises stresses contour using pseudo-static analysis 


\section{RESULTS AND DISCUSSION}

The pseudo-static and frequency response analyses are performed with finite element software. The frequency response analysis used a damping ratio of $5 \%$ of critical. The results linear static and frequency response finite element analysis i.e. the von Mises stress distribution of mounting are presented in Figures 3 and 4 respectively. From the results, von Mises stresses of $178 \mathrm{MPa}$ and $174 \mathrm{MPa}$ were obtained at node 11810 in the linear static and frequency response analysis at $0 \mathrm{~Hz}$, respectively. These two are almost identical. When plot higher frequencies, it will be seen a small divergence from the static cases. This is due to dynamic influences of the first mode shape. Figures 5-8 show the applied time histories, PSD's of narrow band signal (1 peak), corresponding probability density function and cycle histogram, respectively. Figures 9-10 also show the time history and PSD function of wide band signal (2 peaks).

A static analysis comparison has been undertaken between the results from a pseudostatic analysis and the results form a PSD based frequency analysis. With the pseudo-static approach the results caused by each load application point are linearly superimposed at each node of interest. For both methods von Mises stresses were used.

The life contour plots from the frequency response analysis and pseudo-static fatigue analysis results are shown in Figures 11 and 12, respectively. The full set of comparison results for this node is given in Table 1. The dark gray near the circular hole shows the position of the shortest life and the white areas the longest fatigue lives.
MSC Patran 12.0.044 17-Mar-05 13:39:10

Fringe: $30 \mathrm{~N}$, Freq. $=0$, : Stress Tensor, $-($ NON-LAYERED) $($ VONM

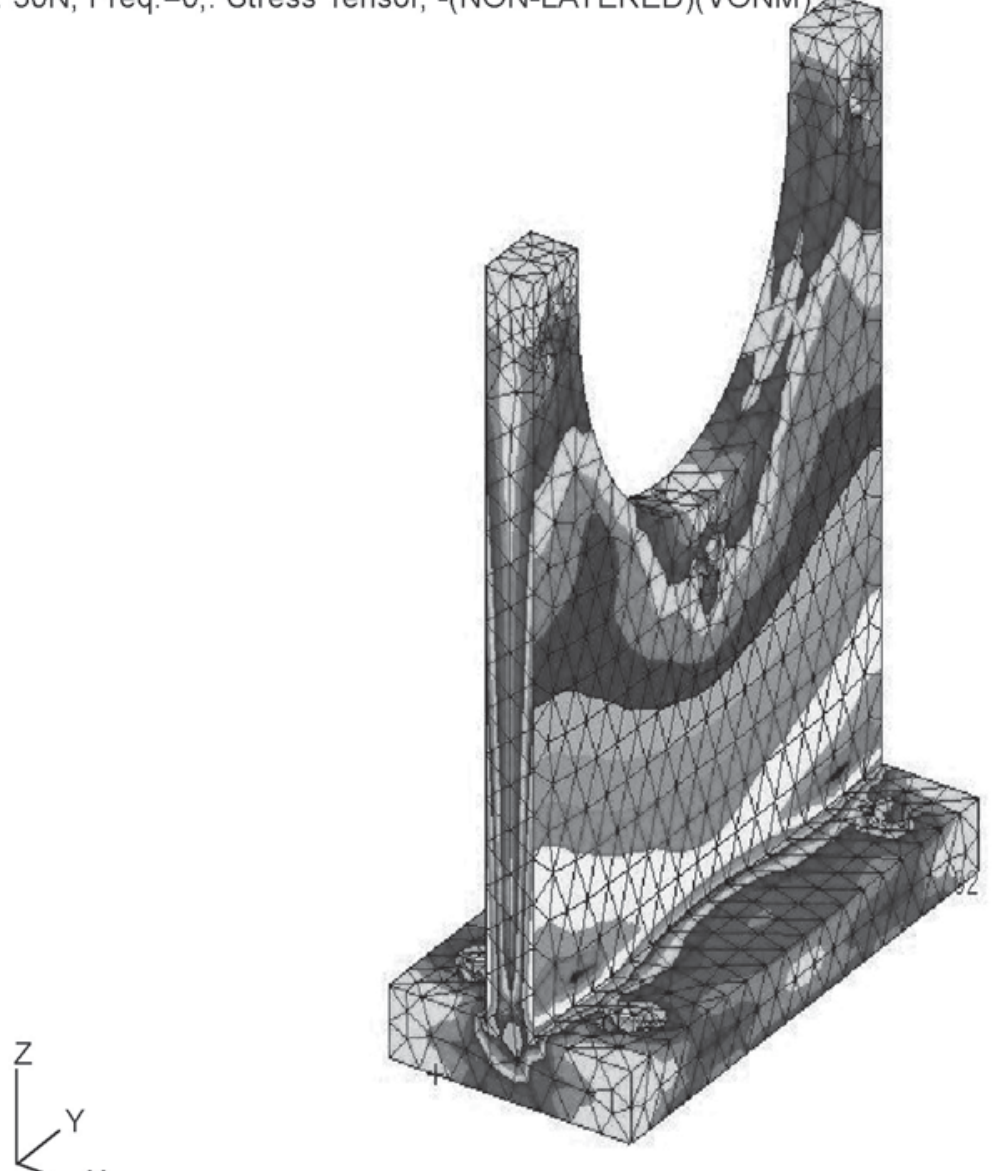

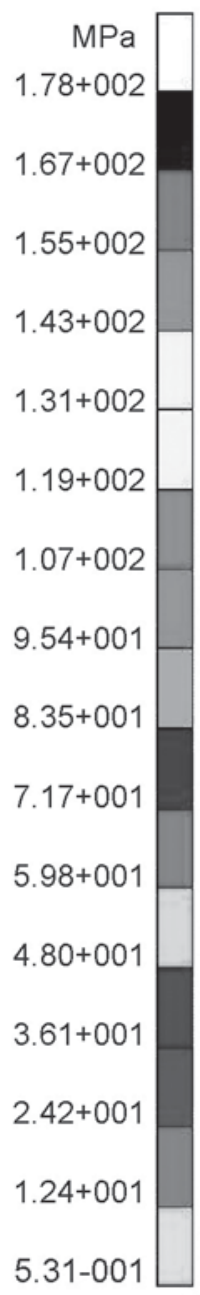

default Fringe:

Max 1.78+002@Nd 11810

Min 5.31-001@Nd 7533

FIGURE 4. Von Mises stresses contour using frequency response analysis for zero (0) $\mathrm{Hz}$ 


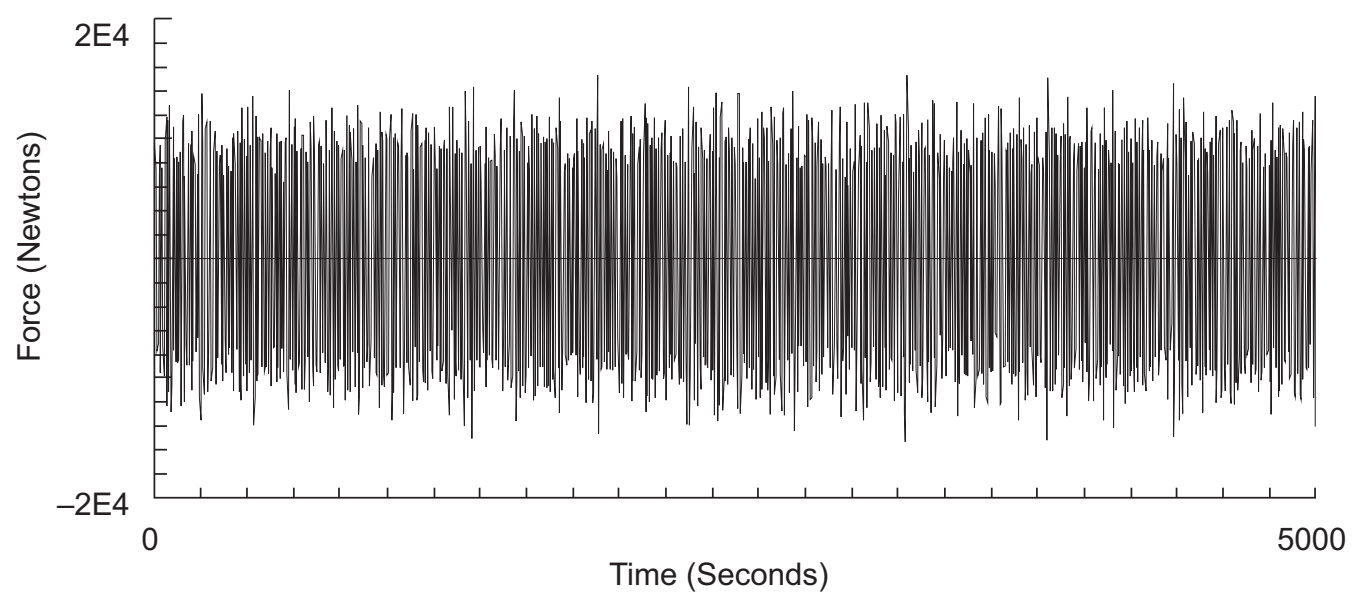

FIGURE 5. Time-load histories

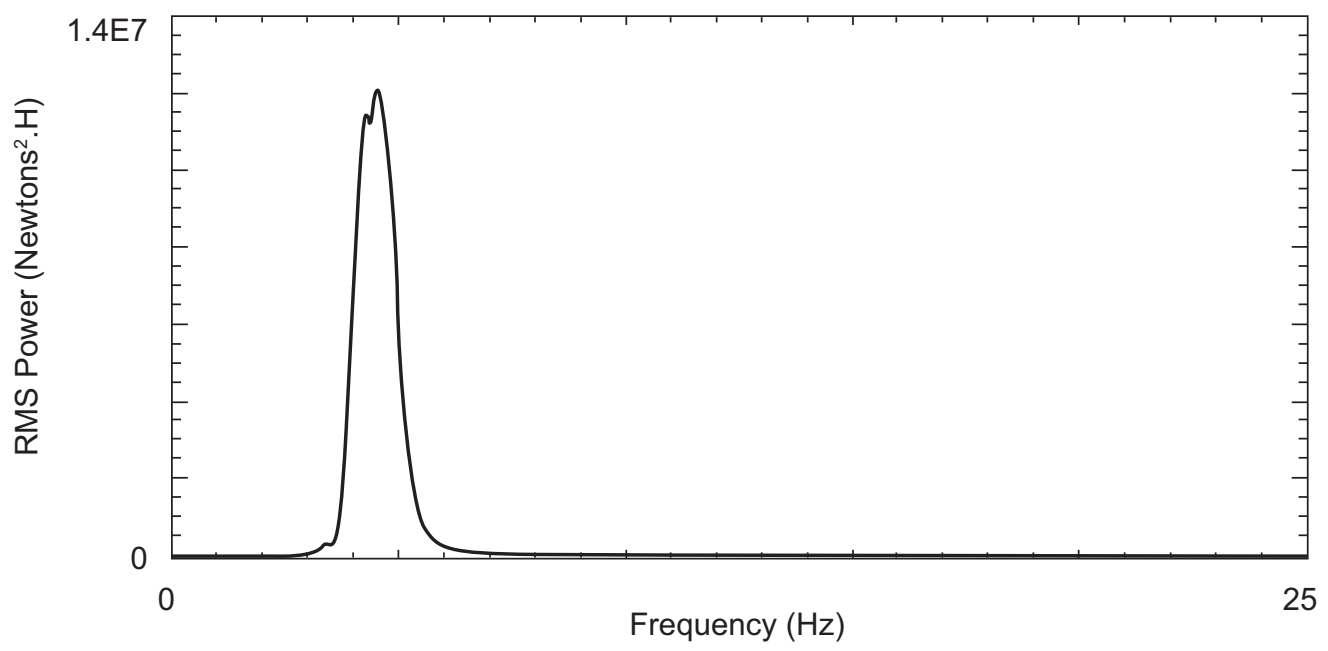

FIGURE 6. Corresponding (Figure 5) power spectral density

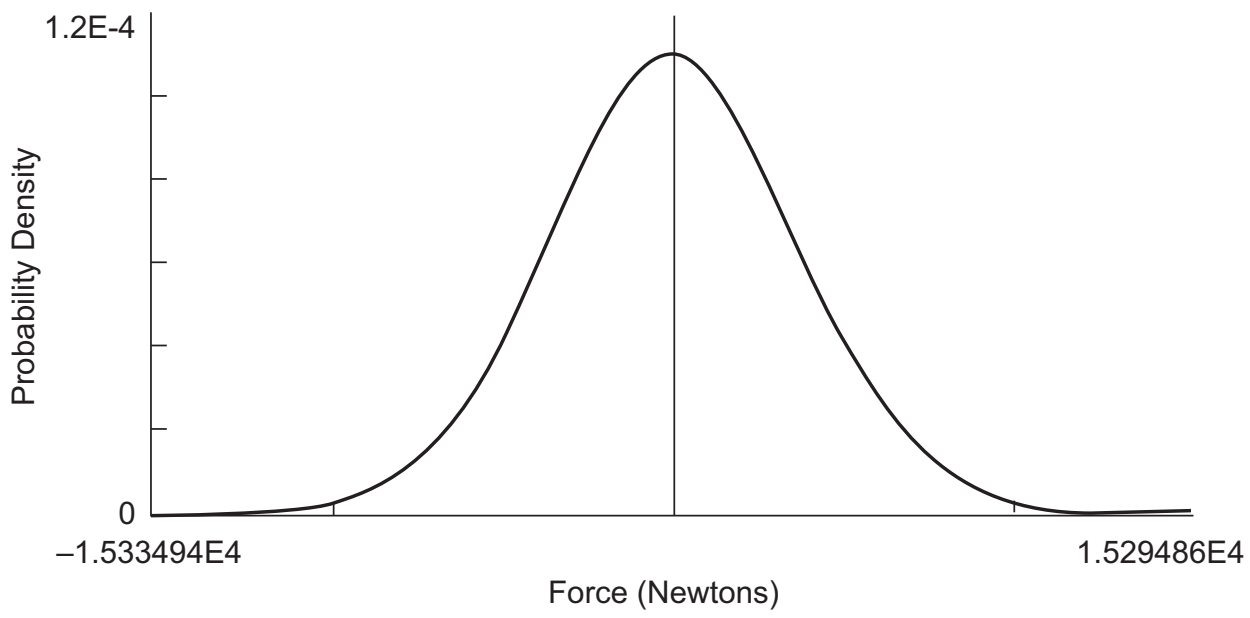

FIGURE 7. Corresponding (Figure 5) probability density function 
Maximum height: 458

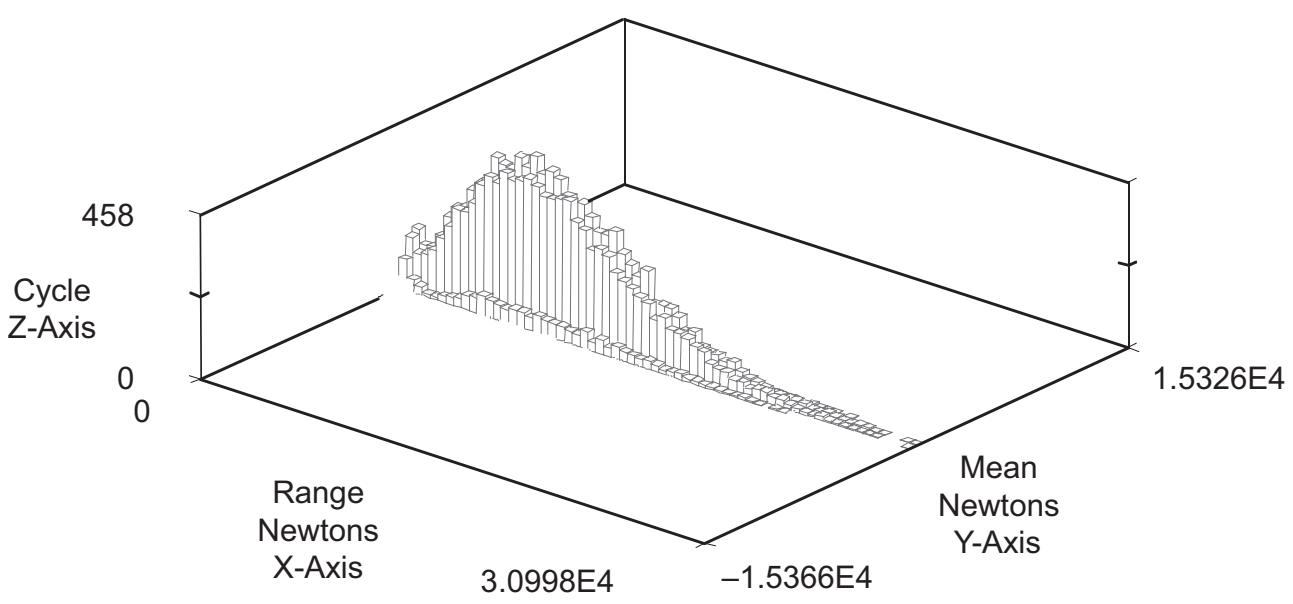

FIGURE 8. Corresponding (Figure 5) cycle histogram

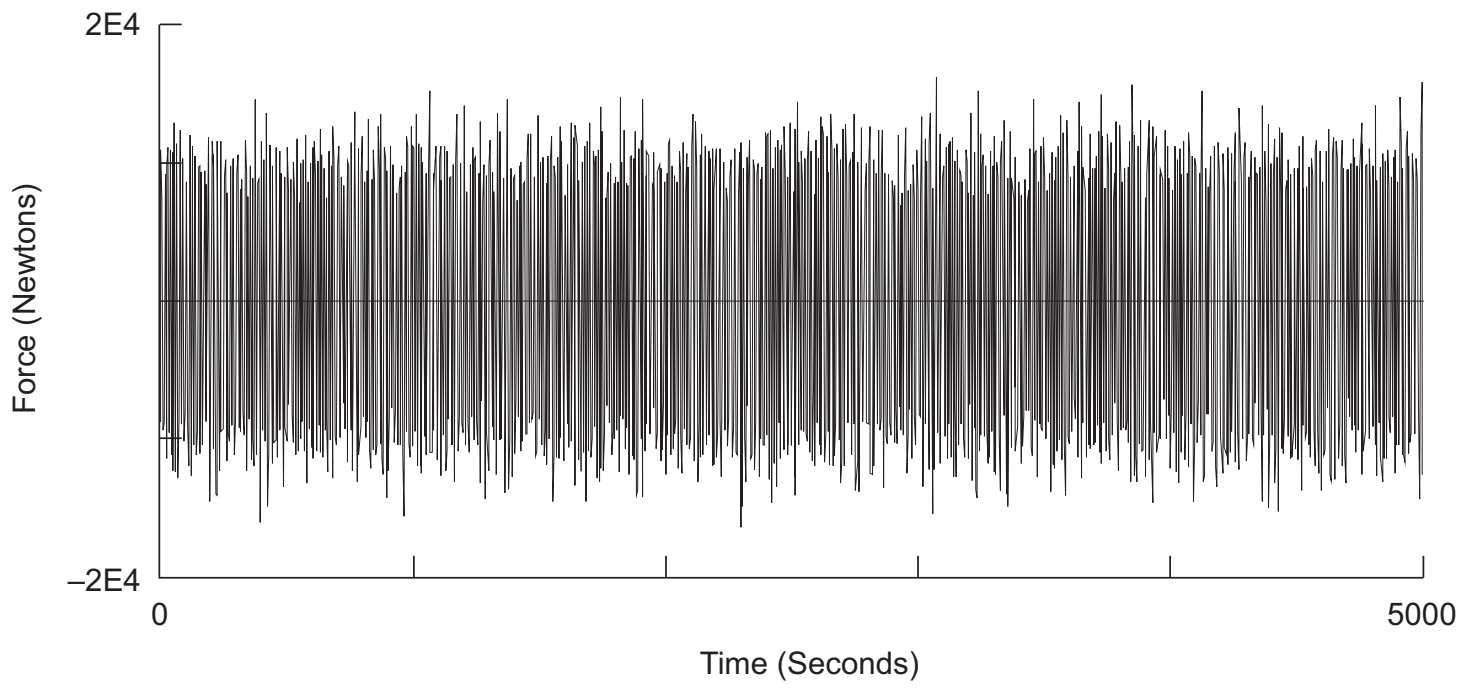

FIGURE 9. Time history of wide band signal

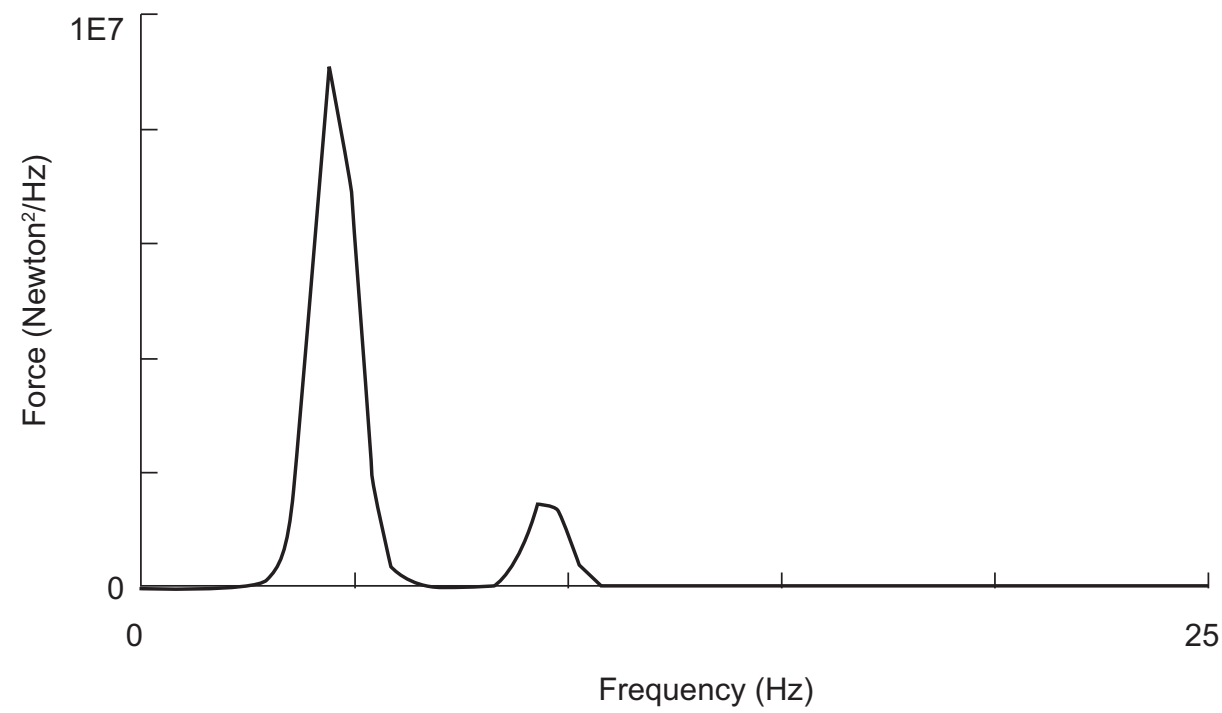

FIGURE 10. PSD distribution of wide band signal 
MSC Patran 12.0.044 18-Mar-05 11:47:20

Fringe:Vibration Analysis, nvcfef_10: Log of Life (Seconds) -(NON-LAYERED_2)

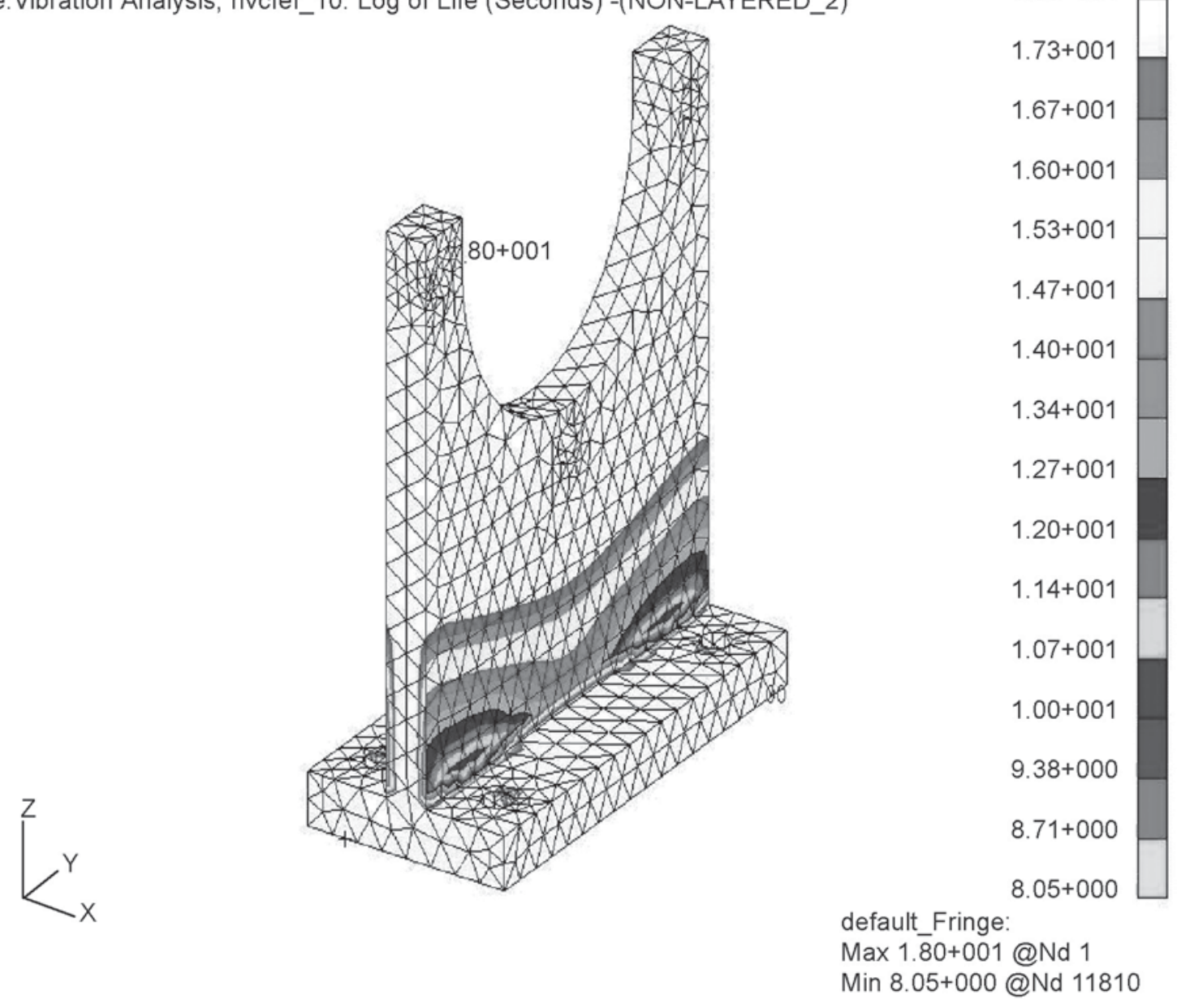

FIGURE 11. Log of life contour using frequency response approach

Frequency resolution of the transfer function is also influence to capture input PSD. The significances of the frequency resolutions are shown in Figures 13 and 14 used FFT buffer size of 1024: $0.9766 \mathrm{~Hz}$ width and 2048: $0.4883 \mathrm{~Hz}$ width respectively. The FFT buffer size defines the resolution of the power spectrum. The buffer must be a power of 2 and of course the longer the buffer, the higher the resolution of the spectral lines. To calculate the resolution divide the Nyquist frequency by half the FFT buffer size. If the Nyquist frequency is $500 \mathrm{~Hz}$ and the FFT buffer size selected is 1024 , then the spectral lines are $500 /(1024 / 2)=0.9766 \mathrm{~Hz}$ apart. Another use of a smaller buffer size is for short data files as these cannot be adequately analyzed with a big buffer, since there may not be enough data to give a good spectral average. Using a smaller buffer size could give a better spectral average at the expense of spectral line width. Even though the total area under each input PSD curve is identical between the two only differences being that one has twice as many points. The dominant factor is the frequency resolution of the transfer function in the important areas of the input PSD. Because transfer function has evenly incremented frequency steps, may skip over certain peaks or valleys in the input PSD. Interpolation only occurs within the input PSD at frequency points found in the transfer function and not those found in the input PSD.

For the purpose of validation, the predicted life listed below will be taken to be the definitive answers.Table 1 shows the comparison between the frequency response analysis method and the conventional time domain Pseudo-static approach. It can be seen that there is $\mathrm{s}$ good agreement between the Pseudo-static and frequency response analysis approaches. The frequency response using Dirlik approach is 
MSC Patran 12.0.044 17-Mar-05 23:24:54

Fringe:Total Life, 11fef_19: Log of Life(Sec),-(NON_LAYERED_2)

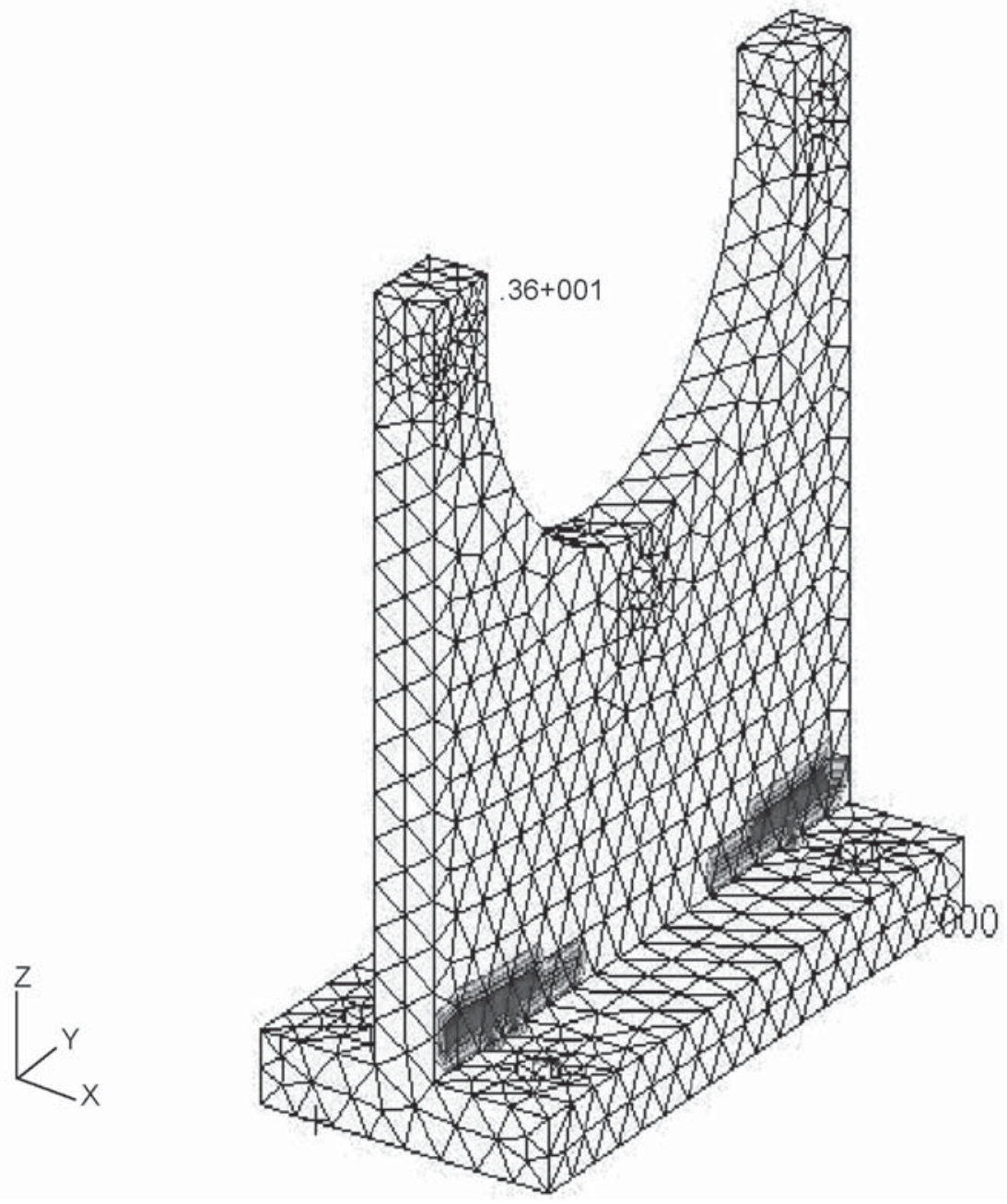

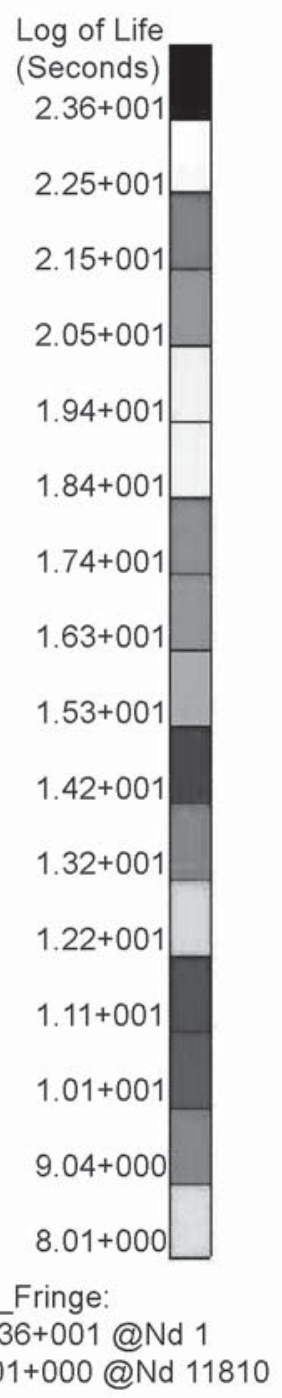

FIGURE 12. Log of life contour using pseudo-static time domain approach

TABLE 1. Predicted fatigue life in seconds between two approaches at critical location (node 11810)

\begin{tabular}{ccc}
\hline Loading conditions & Pseudo-static approach & $\begin{array}{c}\text { Frequency response } \\
\text { analysis }\end{array}$ \\
\hline Narrow band (1 peak) & $1.02 \times 10^{8}$ & $1.12 \times 10^{8}$ \\
Wide band ( 2 peaks) & $6.34 \times 10^{7}$ & $6.52 \times 10^{7}$ \\
\hline
\end{tabular}

considered for the validation. The predicted fatigue life on log-log coordinates using the Pseudo-static and frequency response analysis is presented in Figure 15. The solid straight line in Figure 15 represents the perfect correlation between the pseudo-static and frequency response analysis results i.e. one to one correspondence if the vibration fatigue predicted life exactly equivalent to the pseudostatic predicted life. The two straight dotted lines represent a three times factor indicating a goodness band. Data points that fall above the solid line represent non-conservative estimates, while points below the solid line represent conservative predictions in comparison to the pseudo-static time domain results. It can be seen that the correlation between the two approaches results are well correlated within the expected scatter band. It can be also seen that the frequency response analysis method tended to be conservative due to the data points concentrates on the lower band i.e. with the solid 


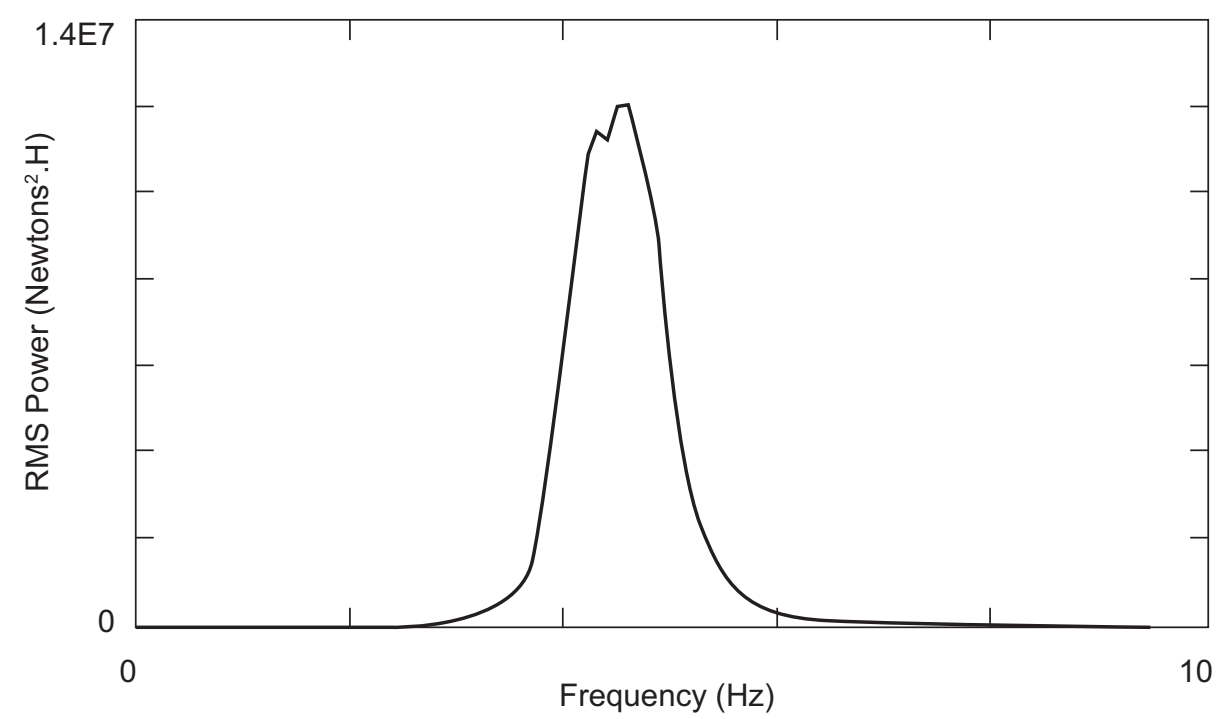

FIGURE 13. Frequency resolution for FFT buffer size of $1024: 0.9766 \mathrm{~Hz}$ width

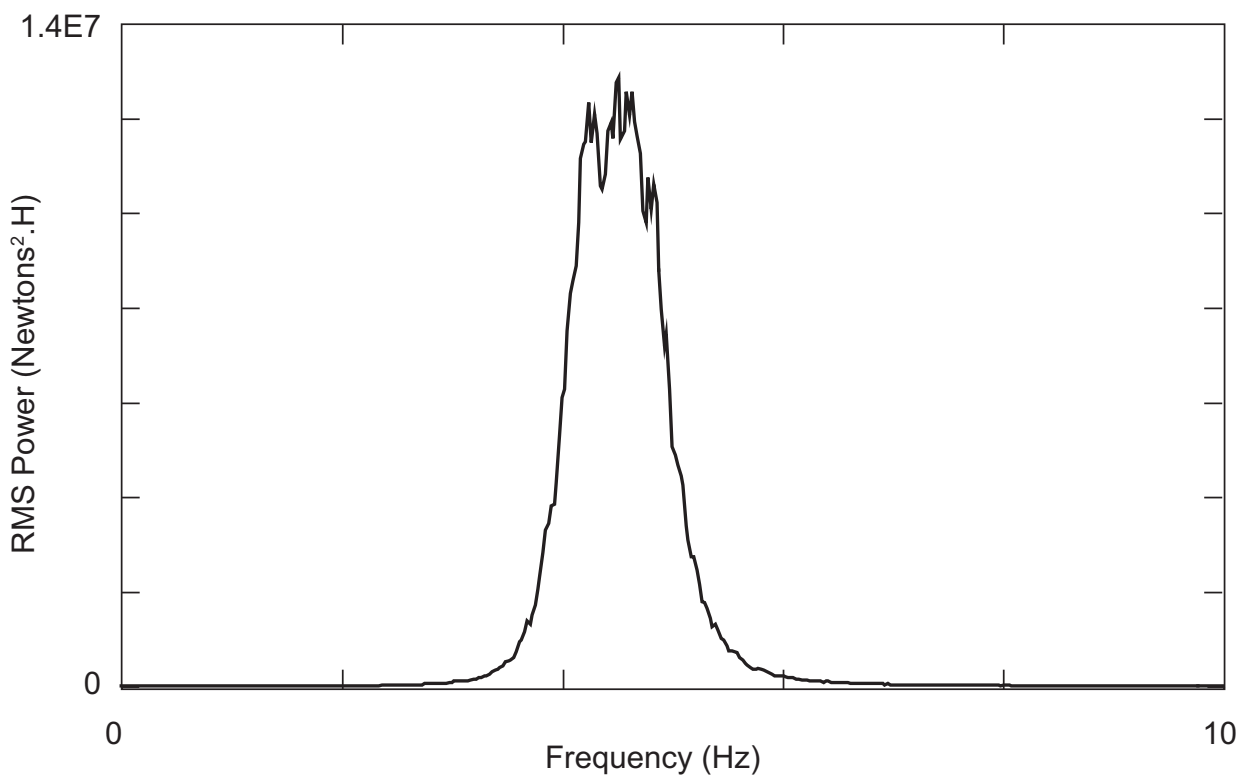

FIGURE 14. Frequency resolution for FFT buffer size of $2048: 0.4883 \mathrm{~Hz}$ width

line and the lower dotted line.

Table 2 shows comparison between the narrow band ( 1 peak) and wide band ( 2 peaks) loading history for all frequency domain approach methods. From the results, it can be seen that the Dirlik method gives the good agreement with the pseudo-static for both cases (narrow band and wide band signal). The narrow band gives good results from the narrow band signal (1 peak) but becomes too conservative prediction when the signal is wide band ( 2 peaks). Tunna breaks down completely for a wide band signal. Wirsching is unconservative prediction and then too conservative as is Steinberg results. Hancock, and Chaudhury and Dover methods result are reasonably well but not as well as the Dirlik predicted result. When the input signal is wide band, the narrow band tends to turn any signal into the narrow band signal making the resulting fatigue prediction extremely and sometimes overly conservative prediction. The Dirlik method found the best results when compared with the corresponding time domain and others frequency response methods. From the above discussions, it is concluded that the Dirlik method is recommended for general usage.

\section{CONCLUSIONS}

The concept of frequency domain fatigue analysis has been presented, where the random loading and response are categorized using 


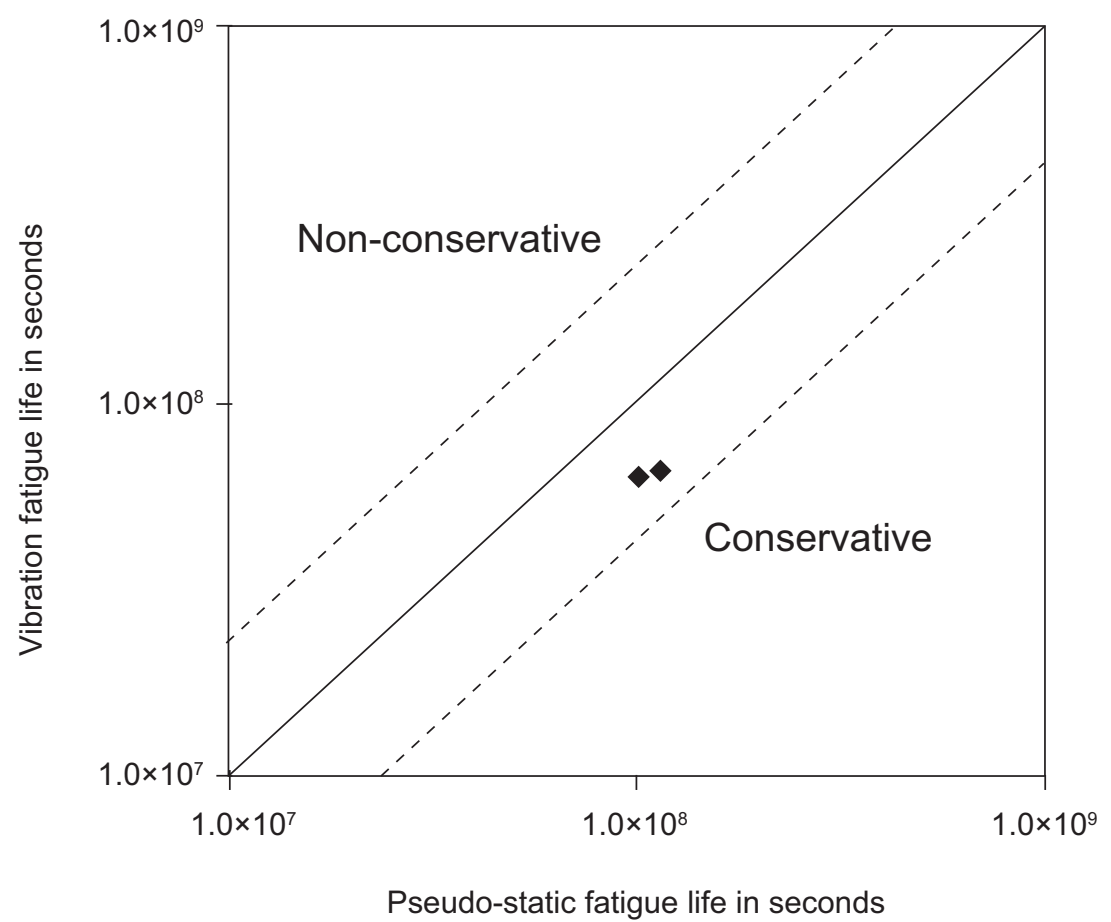

FIGURE 15. Comparison between the fatigue life between the pseudo-static and frequency response analysis

TABLE 2. Predicted fatigue life at most critical location (node 11810) using different frequency response approaches

\begin{tabular}{cccccccc}
\hline & \multicolumn{7}{c}{ Predicted Fatigue life (Seconds) } \\
\cline { 2 - 8 } & $\begin{array}{c}\text { Narrow } \\
\text { band }\end{array}$ & Dirlik & Tunna & Wirsching & Hancock & $\begin{array}{c}\text { Chaudhury } \\
\text { \& Dover }\end{array}$ & Steinberg \\
\hline 1 peak & $9.42 \times 10^{7}$ & $1.12 \times 10^{8}$ & $2.84 \times 10^{8}$ & $1.56 \times 10^{8}$ & $1.23 \times 10^{8}$ & $9.74 \times 10^{8}$ & $1.51 \times 10^{8}$ \\
2 peaks & $3.98 \times 10^{7}$ & $6.52 \times 10^{7}$ & $1.96 \times 10^{9}$ & $6.77 \times 10^{7}$ & $5.68 \times 10^{7}$ & $6.74 \times 10^{7}$ & $6.51 \times 10^{7}$ \\
\hline
\end{tabular}

PSD functions. A state of art of vibration fatigue techniques have been presented. Frequency domain fatigue analysis has been applied to a typical free piston engine component. All the current methods are briefly discussed and conclusions are drawn showing that Dirlik method is recommended for general use. In addition, the frequency response approach can improve understanding of the system dynamic

\section{REFERENCES}

Bendat, J. S. 1964. Probability Functions for Random Responses. NASA report on Contract NAS-54590.

Bishop, N.W.M.,Zhihua, Hu. 1991.The Fatigue Analysis of Wind Turbine Blades Using Frequency Domain Techniques. European Wind Energy Conference (EWEC'91), pp. 246-250,

Bishop, N.W.M. \& Sherratt, F. 1989. Fatigue life prediction from power spectral density data. Part-1,Traditional approaches and part-2 recent behaviors, in terms of frequency characteristics of both structures and loads and their couplings.

\section{ACKNOWLEDGMENTS}

The authors are grateful to Malaysia Government especially Ministry of Science, Technology and Environment under IRPA project (IRPA project no: 03-02-02-0056 PR0025/04-03) for providing financial support. developments. Environmental Engineering. 2(12): 11-19.

Bishop, N.W.M.\& Sherratt, F.2000. Finite element based fatigue calculations. UK: NAFEMS Ltd.

Bolotin, V.V.1984. Random vibrations of elastic systems. The Netherlands: Martinus Nijhoff.

Chaudhury, G.K.\& Dover,W.D.1985. Fatigue Analysis of Offshore Platforms Subject to Sea Wave Loading. International Journal of Fatigue. 7(1): 13-19.

Dirlik, T. 1985. Application of Computers in Fatigue. 
Ph.D. Thesis. University of Warwick, UK.

Kam, J.C.P.\& Dover,W.D. 1988. Fast fatigue assessment procedure for offshore structures under random stress history. Proc. Instn. Civil Engineers. Part 2, 85: 689-700.

MSC. 2005. MSC/FATIGUE user's guide, vol. 1\& 2. MSC. Software Corporation, USA.

Newland, D.E. 1993. An introduction to random vibrations, spectral and wavelet analysis, $3^{\text {rd }}$ ed. Essex, UK: Longman Scientific and Technical.

Rice, S.O. 1954. Mathematical analysis of random noise. selected, papers on noise and stochastic processes. Dover. New York.

Soong, T.T. \& Grigoriu, M. 1993. Random vibration of mechanical and structural systems. UK:Prentice Hall International Ltd.
Stephens, R.I., Fatemi, A., Stephens R.R. \& Fuchs H.O. 2001. Metal fatigue in engineering. USA: John Wiley and Sons Inc.

Suresh, S. 2002. Fatigue of materials. UK: Cambridge University Press.

Tunna, J.M. 1986. Fatigue life prediction for gaussian random loads at the design stage. Fatigue Fracture Engineering, Mat. Structure. 9(3): 169184.

Wirsching, P.,Paez,T.\& Oritz, K. 1995. Random vibration, theory and practice. USA: John Wiley and Sons Inc.

Wirsching, P.H. \& Light, M.C. 1980. Fatigue under wide band random loading. Journal of Structural Div., ASCE. 1593-1607. 